\title{
PROSES PELAKSANAAN AKAD QARDH WAL IJARAH PADA PRODUK TALANGAN HAJI PADA BANK SYARIAH MANDIRI KANTOR CABANG PEMBANTU PADANG PANJANG
}

\author{
Awaluddin \\ Jurusan Perbankan Syariah STAI Solok Nan Indah \\ Jl. Adinegoro No.59 By Pass KTK Kota Solok \\ e-mail: aawa165@yahoo.com
}

\begin{abstract}
The agreement of qardh wal ijarah for the product of pilgrimage bailout has been implemented by some sharia banks In Indonesia following fatawa of DSN No. 29/DSN-MUI /IV/2002 about product of pilgrimage bailout. In one side, this implementation made much easier for those to realize their dreams to go for pilgrimage. On the other side, such implementation raised a very challenging question whether the implemtatation has fulfilled the rules expected by the fatawa. Based on a study conducted, it revealed that the process of proposing product of pilgrimage bailout by the customers of BSM of Kota Padang Panjang supporing branch office was done as it was required by the mechanism by considering $5 C$ factors as standard procedure for realizing the finance. In realizing pilgrimage bailout, this institution referred to the fatawa of MUI about pilgrimage bailout in which the customer should have settled the bailout before the depart to pilgrimage. This also implies that the bank has the rights to cancel the customers' departure in the case of inability to settle the bailout. Dealing with this implementatiom, bank is benefited from the ujrob based on the agreement between the bank and the customer. Customers, on the other hand, are required to pay expenses dealing administration and insurance as the consequences of the agreement. Furthermore, the customers are benefitted from gaining portion abead and are allowed to pay in installments for the pilgrimage.
\end{abstract}

Kata kunci: akad qardh, ijarah, talangan haji

\section{PENDAHULUAN}

K emunculan bank syariah sebagai suatu prinsip-prinsip yang dianut dalam syariah Islam menghadirkan nuansa baru dalam kehidupan sosial ekonomi masyarakat termasuk Indonesia. Sistem yang dipraktekkan bank syariah seakan menjadi salah satu harapan solusi berbagai kondisi keterpurukan ekonomi yang sedang dialami dunia saat ini. Perkembangan industri perbankan syariah secara informal telah dimulai sebalum dikeluarkannya kerangka hukum formal sebagai landasan operasional perbankan syarah di Indonesia. Sebelum tahun 1992 telah didirikan beberapa badan usaha pembiayaan non bank yang telah menerapkan konsep bagi hasil dalam kegiatan operasionalnya. Hal tersebut menunjukkan kebutuhan masyarakat akan hadirnya institusi-institusi keuangan yang sesuai syariah. Untuk menjawab kebutuhan masyarakat bagi terwujudnya sistem perbankan yang sesuai syariah, pemerintah telah memasukkan sistem tersebut ke dalam UU No. 7 Tahun 1992 tentang Perbankan dan secara implisit telah membuka peluang kegiatan usaha perbankan yang memiliki dasar operasional bagi hasil yang secara rinci dijabarkan dalam Peraturan Pemerintah No. 72 Tahun 1992 tentang bank berdasarkan prinsip bagi hasil. Dan dilanjutkan dengan UU No. 10 Tahun 1998, yang mengakui adanya (Dual Banking Sistem) sebagai dasar hukum 
perbankan syariah di Indonesia yang menandai dimulainya era sistem perbankan ganda.

Kemudian dilanjutkan dengan Undangundang Nomor 21 Tahun 2008 yang menjelaskan bahwa perbankan syariah adalah segala sesuatu yang menyangkut tentang bank syariah dan unit usaha syariah mencakup kelembagaan, kegiatan usaha, serta cara dan proses dalam melaksanakan kegiatan usahanya. Setelah dikeluarkannya landasan hukum formal diatas, perbankan syariah semakin berkembang di Indonesia, dan mulai menawarkan berbagai macam produk, yang dapat dibagi menjadi tiga bagian besar, yaitu:produk penghimpun dana (funding), produk penyaluran dana (financing) dan produk jasa (service). Perbankan syariah selalu mengembangkan produknya dalam rangka memperoleh keuntungan dan memberi kepuasan kepada nasabah, salah satu produknya yaitu Talangan Haji. Dapat dilihat pada salah satu perbankan syariah yang ada yaitu Bank Syariah Mandiri (BSM). Dana Talangan haji yaitu pembiayaan dengan menggunakan akad Qardh wal ijarah yang diberikan kepada nasabah calon haji dalam rangka memperoleh nomor porsi atau pelunasan BPIH (Biaya Penyelenggaraan Ibadah Haji) (surat Edarana Pembiayaan Bank Indonesia, no.10/028/PEM, tanggal 1 September, 2008)

Untuk membantu masyarakat yang ingin menunaikan ibadah haji tetapi tidak mempunyai dana yang cukup untuk pengambilan porsi, BSM mempunyai solusi untuk membantu masyarakat yang ingin menunaikannya, BSM menyediakan produk Talangan haji dengan menggunakan akad Qardh wal Ijarah. Dari uraian di atas perlu untuk melakukan penelitian mengenai bagaimana proses pelaksanaan akad Qardh wal Ijarah pada produk Talangan Haji pada Bank Syariah Mandiri Kantor Cabang Pembantu Padang Panjang.

\section{METODE PENELITIAN}

\section{Jenis Penelitian}

Penelitian ini menggunakan pendekatan kualitatif dan penulis melaksanakan penelitian lapangan atau "field research" sedangkan metode yang digunakan adalah deskriptif kualitatif. Dimana dalam hal ini peneliti mempunyai tujuan spesifik yaitu untuk mengungkapkan mengenai bagaimana proses pelaksanaan akad Qard wal ijarah pada produk Talangan Haji yang dilakukan oleh Bank Syariah Mandiri Kantor Cabang Pembantu Padang Panjang.

\section{Sumber Data}

\section{Sumber Data Primer}

Sumber data primer adalah sumber data pokok atau yang paling utama dalam penelitian. Yang menjadi sumber data primer dalam penalitian ini adalah Operasional Officer Bank Syariah Mandiri Kantor cabang Pembantu Padang Panjang yang berperan dalam pelaksanaan produk Talangan Haji

\section{Sumber Data Sekunder}

Sumber data sekunder adalah sumber data yang bukan merupakan kebutuhan pokok dalam penelitian namun masih diperlukan keberadaannya. Sumber data sekunder dalam penelitian ini adalah data yang diperoleh dari bahan referensi atau dokumen yang berkaitan dengan masalah yang dibahas, bersumber dari buku terkait, dan dokumen-dokumen yang ada pada PT Bank Syariah Mandiri Kantor Cabang Pembantu Padang Panjang.

\section{Teknik Pengumpulan Data}

Dalam penelitian ini penulis menggunakan teknik pengumpulan data sebagai berikut: 


\section{Observasi}

Penulis melakukan pengmatan melalui kegiatan magang, dan ikut menyaksikan bagaimana pengelolaan produk Talangan Haji pada PT Bank Syariah Mandiri Kantor Cabang Pembantu Padang Panjang

\section{Wawancara}

Penulis melakukan wawancara dengan staf dan pimpinan dan masyarakat sekitar PT Bank Syariah Mandiri Kantor Cabang Pembantu Padang Panjang wawancara dengan staf dan pimpinan dan masyarakat sekitar PT Bank Syariah Mandiri Kantor Cabang Pembantu Padang Panjang

\section{Studi Kepustakaan}

Penelitian ini melakukan kegiatan mengambil berbagai topik mengenai judul dari UU, PBI, dan buku-buku yang menggambarkan tentang penelitian sejenis

\section{Teknik Analisa Data}

Dari data yang didapat metode yang akan digunakan untuk menganalisis data tersebut adalah dengan menggunakan metode analisa kualitatif dengan cara membandingkan data yang diperoleh dengan hasil wawancara dan hasil observasi dan dokumentasi, lalu ditarik kesimpulan.

\section{PEMBAHASAN}

\section{Pengertian Akad}

Akad dalam bahasa Arab yaitu al-aqad, jamaknya al-uqud, berarti ikatan atau mengikat (al-rabth). Menurut terminologi hukum Islam, akad adalah pertalian antara penyerahan (ijab) dan penerimaan (qabul) yang dibenarkan oleh syariah, yang menimbulkan akibat hukum terhadap objeknya. Menurut Abdul Razak AlSanhuri dalam Nadhariyatul", akad (aqdi) adalah kesepakatan dua belah pihak atau lebih yang menimbulkan kewajiban hukum yaitu konsekuensi hak dan kewajiban yang mengikat pihak-pihak yang terkait langsung maupun tidak langsung dalam kesepakatan tersebut (Sri Nurhayati, dkk., 2009: 70). Secara etimologi (bahasa) akad mempunyai beberapa arti, antara lain:

1. Mengikat (ar-rabthu) yaitu mengumpulkan dua ujung tali dan mengikat salah satunya dengan yang lain sehingga bersambung, kemudian keduanya menjadi sebagai sepotong benda

2. Sambungan (aqdatun) yaitu sambungan yang memegang kedua ujung itu dan mengikatnya

3. Janji (Al- 'Ahdu) sebagaimana yang dijelasakan dalam Alquran:

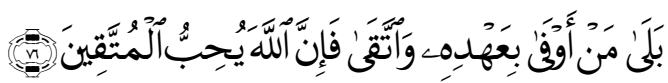

Ya, siapa saja menepati janjinya dan takut kepada Allah, sesungguhnya Allah mengasihi orang-orang yang takwa." (QS. Ali- Imran [3]: 76)

Menurut istilah (terminologi) yang dimaksud dengan akad adalah:

1. Akad yaitu tasarruf antara dua pihak dan timbulnya ikatan-ikatan dan kewajiban yang dipelihara oleh keduanya.

2. Perikatan ijab kabul yang dibenarkan syara' yang menetapkan keridaan kedua belah pihak

3. Berkumpulnya serah terima diantara dua belah pihak atau perkataan seseorang yang berpengaruh pada kedua pihak

4. Terkumpulnya persyaratan serah terima atau sesuatu yang menunjukkan adanya serah terima yang disertai dengan kekuatan hukum. (SohariSahrani, t.th: t.h.)

Di dalam hukum syariah, kesepakatan antara dua pihak atau lebih untuk bekerja sama dalam suatu usaha atau suatu transaksi diwujudkan dalam bentukakad. 
134

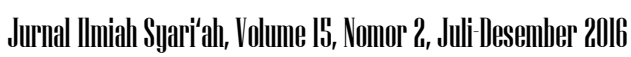

Akad merupakan perjanjian dan pemufakatan yang dilakukan oleh dua pihak atau lebih, di mana isi kesepakatan itu tidak boleh menyimpang dan harus sejalan dengan hukumhukum syariah. Akad akan menjadi semacam pedoman dalam bertransaksi, sekaligus mengandung konsekuensi bagi para pihak untuk menaatinya (Yusak Laksamana, 2009: 8). Akad adalah kontrak antara dua pihak atau lebih yang bersifat mengikat masing-masing pihak yang terlibat termasuk pengenaan sanksi manakala terjadi wanprestasi atas kesepakatan yang disepakati (Sunarto Zulkifli, 2003: 23). Dalam perbankan syariah akad yang dilakukan memilki konsekuensi duniawi dan ukhrawi karena akad yang dilakukan berdasarkan hukum Islam. Seringkali nasabah berani melanggar kesepakatan atau perjanjian yang telah dilakukan bila hukum itu hanya berdasarkan hukum positif belaka, tapi tidak demikian bila perjanjian tesebut memilki pertanggungjawaban hingga yaumil qiyamah nanti (Muhammad Syafi'i Antonio, 2001: 29). Jadi, menurut penulis akad adalah perjanjian yang terdiri dari dua belah pihak dan mengikat kedua pihak tersebut, serta terdapat ketentuan-ketentuan yang harus disepakati.

\section{Landasan Hukum Akad}

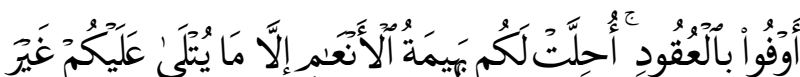
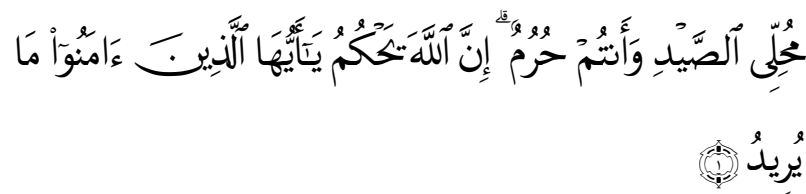

Hai orang-orang yang beriman, penuhilah aqad-aqad itu. Dihalalkan bagimu binatang ternak, kecuali yang akan dibacakan kepadamu. (yang demikian itu) dengan tidak menghalalkan berburu ketika kamu sedang mengerjakan haji. Sesungguhnya Allah menetapkan hukum-hukum menurut yang dikehendaki-Nya. (Q.S. al-Maidah [5]:1)
Allah memulai tuntunan-Nya ini dengan menyeru: hai orang-orang yang beriman, untuk membuktikan kebenaran iman kalian, penuhilah akad-akad itu, yaitu baik akad antara kamu dengan Allah yang terjalin melalui pengakuan kamu dengan beriman kepada Nabi-Nya atau melalui nalar yang dianugerahkan-Nya kepada kamu, demikian juga perjanjian yang terjalin antara kamu dengan sesama manusia, bahkan perjanjian antara kamu dengan diri kamu sendiri. Bahkan semua perjanjian, selama tidak mengandung pengharaman yang halal atau penghalan yang haram.

Salah satu akad yang perlu diingat adalah bahwa telah dihalalkan bagi kamu apa yang sebelum ini diharamkan atas Ahlul-Kitab yaitu binatang ternak. Setelah disembelih secara sah. Yakni dihalalkan bagi kamu memakannya, memanfaatkan kulit, bulu, tulang, dan lain-lain dari binatang ternak itu, kecuali atau tetapi yang akan dibacakan kepada kamu dalam Alquran surat al-An'am dan ayat ketiga surat ini serta terdapat dalam Sunnah yang shahih, maka itu adalah haram, antara lain sabda Rasulullah Saw yang mengharamkan semua binatang yang bertaring. Yang demikian itu dengan tidak menghalalkan, baik dengan melakukan maupun sekedar meyakini kehalalan berburu ketika kamu sedang dalam keadaan hurum, yakni berihram untuk melaksanakan haji, umrah, atau memasuki Tanah Haram. Sesungguhnya Allah menetapkan hukum-hukum halal atau haram, boleh atau tidak menurut yang dia kehendaki, dan berdasar pengetahuan dan hikmah-Nya. Karena itu penuhilah ketentuan-ketentuan-Nya.

Berusahalah memenuhi latar belakangnya. Bila kamu menemui hikmah dan rahasianya maka bersyukurlah dan bila tidak atau belum kamu temukan, maka landaskanlah dengan penuh ketaatan dan rendah hati (M. Quraish Shihab, 2009: 6). Maksud dari akad pada ayat ini adalah akad atau perjanjian mengenai janji umat manusia kepada Allah dan perjanjian yang 
dibuat oleh manusia dalam pergaulan sesamanya.

\section{Rukun dan Syarat Akad}

\section{Rukun}

1. 'Aqid (orang yang berakad) yaitu para pihak yang melakukan akad (penjual dan pembeli, penyewa dan yang menyewakan, karyawan dan atasan, shahibul maal dan mudharib, mitra dengan mitra dalam musyarakah dan sebagainya)

2. Ma'qud'alaih (objek akad) merupakan sebuah konsekuensi yang harus ada dengan dilakukannya suatu transaksi tertentu. Obyek jual beli adalah barang dagangan, obyek mudharabah dan musyarakah adalah modal dan kerja, obyek sewa menyewa adalah manfaat atas barang yang disewakan dan seterusnya.

3. Maudhu 'al'aqad ialah tujuan atau maksud pokok mengadakan akad. Dalam akad jual beli tujuan pokoknya ialah memindahkan barang dari penjual kepada pembeli dengan diberi ganti. Tujuan pokok akad hibah ialah memindahkan barang dari pemberi kepada yang diberi tanpa ada pengganti (wadh)

4. Sighat ialah ijab dan kabul. Ijab ialah permulaan penjelasan yang keluar dari salah seorang yang berakad sebagai gambaran kehendaknya dalam mengadakan akad, Kabul ialah perkataan yang keluar dari yang berakad pula yang diucapkan setelah adanya ijab.

\section{Syarat Akad}

1. Pihak yang melakukan akad itu telah cakap bertindak hukum (mukallaf) atau jika obyek akad itu merupakan milik orang yang tidak atau belum cakap bertindak hukum maka harus dilakukan oleh walinya.

2. Objyek akad syaratnya adalah:

a. Sesuatau yang di akadkan ada ketika akad, maka tidak sah melakukan akad terhadap sesuatu yang tidak ada seperti jual beli ikan yang masih dalam air.

b. Obyek akad adalah sesuatu yang dibolehkan syariat, maka tidak benar melakukan akad terhadap sesuatu yang dilarang agama seperti jual beli darah, narkoba dan lain-lain

c. Dapat diserahterimakan ketika akad, maka tidak sah melakukan akad terhadap terhadap sesuatu yang tidak dapat diserah terimakan seperti jual beli burung di udara.

d. Obyek yang diakadkan diketahui oleh pihak-pihak yang berakad

e. Bermanfaat, baik manfaat yang diperoleh berupa materi, maupun inmateri

\section{Jenis-jenis Akad}

Secara umum dalam ekonomi syariah ada dua jenis akad yaitu tabarru' dan tijarah

1. Tabarru' adalah akad yang digunakan untuk transaksi nonkomersial, bertujuan untuk kebaikan atau tolong menolong, dan tidak diperkenankan mengambil keuntungan atas transaksi yang terjadi, namun demikian dalam akad tabarru' masih diperbolehkan adanya pembebanan sejumlah uang sebagai biaya atas terjadinya transaksi. Contoh: untuk mencatat suatu transaksi pinjam meminjam uang diperlukan biaya administrasi sebesar Rp. 100.000,00 maka berapapun nilai transaksi yang terjadi, akan dibutuhkan biaya yang sama yaitu sebesar Rp. 100.000,00.

2. Tijarah adalah akad-akad yang digunakan untuk transaksi komersial atau bisnis. Karenanya dalam akad tijarah para pihak yang bertransaksi dapat menyepakati adanya pengambilan keuntungan, termasuk konsekuensi yang harus ditanggung para pihak bila transaksi terjadi tidak menghasilkan keuntungan. 
136

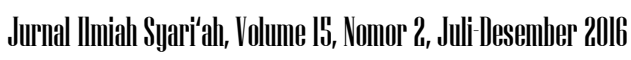

\section{Kombinasi Akad}

Sebuah transaksi terkadang tidak hanya melibatkan satu akad melainkan beberapa akad. Namun demikian ada kondisi yang harus dihindari dalam melakukan kombinasi antara akad, antara lain:

1. Penggunaan dua akad dalam satu transaksi secara bersamaan tidak dibenarkan secara syariah, jika memenuhi kondisi berikut:

a. Menyangkut pihak yang sama

b. Menyangkut obyek yang sama

c. Dalam rentang waktu yang sama

2. Ta'aluq yaitu mengaitkan suatu akad dengan akad lainnya. Misalnya, peminjaman dana dapat dilakukan asalkan bersedia menikahi putrinya.

Kombinasi akad dapat dilakukan antara lain:

a. Antara akad tabarru' dengan akad tabarru' Kombinasi antara kedua akad ini tetap menghasilkan akad tabarru' yang berorientasi non- profit, di mana salah satu pihak tidak boleh mengambil keuntungan dari transaksi. Contoh : kombinasi antara akad wakalah dan akad waqaf, yakni transaksi dimana suatu pihak memberikan hak perwakilan mengumpulkan waqaf kepada pihak lain,

b. Antara akad tijarah dengan akad tijarah

Kombinasi kedua akad ini menghasilkan akad tijarah yang berorientasi profit. Contoh: kombinasi akad bai' dan akad ijarah, yakni transaksi di mana suatu pihak melakukan pembelian obyek tertentu dengan akad bai' dan kemudian menyewakannya kembali kepada pihak lain dengan akad ijarah.

c. Antara akad tabarru' dengan akad tijarah

Kombinasi akad ini memungkinkan salah satu pihak mengambil keuntungan dari transaksi.

Contoh: kombinasi akad rahn dan akad ijarah, yakni transaksi di mana suatu pihak menerima pinjaman dengan jaminan tertentu. Jaminan tersebut kemudian dipelihara pihak pemberi pinjaman dengan menggunakan akad ijarah. Pihak pemelihara memungut keuntungan (profit) dari proses pemeliharaan (M. Quraish Shihab, 2009: 24).

Menurut penulis konbinasi akad ini boleh dilakukan asalkan tidak mengandung unsur riba, seperti judul tulisan ini Akad Qardh wal ijarah, di mana qardh merupakan akad sosial sementara untuk ijarah bank mengambil keuntungan berupa sewa atas pengambilan porsi haji.

\section{Berakhirnya Akad}

Para ulama figh menyatakan bahwa suatu akad dapat berakhir apabila:

1. Berakhirnya masa berlaku akad itu

2. Dibatalkan oleh pihak-pihak yang berakad

3. Jika akad bersifat mengikat, akad dikatakan berakhirjika:

a. Jual beli itu fasad,

b. Berlakunya khiyar syarat, khiyar aib, atau khiyar majelis,

c. Akad itu tidak dilaksanakan oleh salah satu pihak

d. Tercapainya tujuan akad itu secara sempurna

4. Salah satu pihak yang berakad meninggal dunia (Nasrun Haroen, 2000: 108)

\section{Akad Ijarah \\ Pengertian Akad Ijarah}

Menurut Sayyid Sabiq dalam Figh Sunnah, al-ijarah berasal dari kata al-ajru yang berarti al'iwadhu yang berarti ganti atau kompensasi. Ijarah dapat didefinisikan sebagai akad pemindahan hak guna (manfaat) suatu barang atau jasa dalam waktu tertentu dengan dengan pembayaran upah sewa (ujrah) tanpa diikuti dengan pemindahan kepemilikan atas barang itu 
sendiri. Jadi ijarah dimaksudkan untuk mengambil manfaat atas suatu barang atau jasa (mempekerjakan seseorang) dengan jalan penggantian (membayar sewa atau upah dengan jumlah tertentu) (Srinurhayati -Wasilah, t.th.: 216).

Menurut MA. Tihami, ijarah adalah akad (perjanjian) yang berkenaan dengan kemanfaatan (mengambil manfaat sesuatu) tertentu, sehingga sesuatu itu legal untuk diambil manfaatnya, dengan memberikan pembayaran (sewa) tertentu (Sohari Sahrani, t.th: 167).

\section{Landasan Hukum Akad Ijarah}

\section{Alquran}

Artinya: "Apakah mereka membagi-bagi rahmat Tuhan-mu? Kami telah menentukan antara mereka penghidupan mereka dalam kehidupan dunia, dan kami telah meninggikan sebagian yang lain beberapa derajat, agar sebagian mereka dapat memepergunakan yang lain. Dan rahmat Tuhanmu lebih baik dari apa yang mereka kumpulkan" (Q.S. Az-Zukhruf [43]:32)

\section{As-Sunnah}

Diriwayatkan dari Ibnu Abbas, bahwa Rasulullah Saw bersabda: "Berbekamlah kamu, kemudian berikanlah olehmu upahnya kepada tukang bekam itu." (HR. Bukhari dn Muslim) (Srinurhayati -Wasilah, t.th.: 219)

3. Fatwa Dewan Syari'ah Nasional

No: 09/DSN- MUI/ IV/2000 tentang Pembiayaan Ijarah

Ketentuan Obyek Ijarah, Obyek ijarah adalah manfaat dari penggunaan barang atau jasa Manfaat barang atau jasa harus bisa dinilai dan dapat dilaksanakan dalam kontrak. Manfaat barang atau jasa yang dibolehkan (tidak diharamkan) Kesanggupan memenuhi manfaat harus nyata dan sesuai dengan syariah Manfaat harus dikenali secara spesifik sedemikan rupa untuk menghilangkan jahalah (ketidaktahuan) yang akan mengakibatkan sengketa.Spesifikasi manfaat harus dinyatakan dengan jelas, termasuk alam jangka waktunya. Bisa juga dikenali dengan spesifikasi atau identifikasi fisik.

Sewa atau upah adalah sesuatu yang diperjanjikan dan dibayar nasabah kepada LKS sebagai pembayaran manfaat. Sesuatu yang dapat dijadikan harga dalam jual beli dapat pula dijadikan sewa atau upah dalam ijarah Pembayaran upah atau sewa boleh berbentuk jasa (manfaat lain) dari jenis yang sama dengan obyek kontrak Kelenturan (flexibility) dalam menentukan sewa atau upah dapat diwujudkan dalam ukuran waktu, tempat danjarak

\section{Pembatalan dan Berakhirnya Akad Ijarah}

Ijarah adalah jenis akad yang lazim yaitu akad tidak membolehkan adanya fasakh pada salah satu pihak, karena ijarah merupakan akad pertukaran kecuali bila didapati hal-hal yang mewajibkan fasakh. Ijarah akan menjadi fasakh (batal) bila terdapat hal-hal berikut:

1. Terjadinya cacat pada barang sewaan yang terjadi pada tangan penyewa.

2. Rusaknya barang yang disewakan.

3. Terpenuhinya manfaat yang diadakan atau berakhirnya masa yang telah ditentukan.

4. Menurut Hanafiyah boleh fasakh ijarah dari salah satu pihak (Sohari Sahrani, t.th: 173).

Pelaksanaan Akad Qard wal Ijarah pada Produk Talangan Haji di BSM Muaro Kalaban

\section{Pengertian talangan haji}

Talangan haji adalah pembiayaan dengan mengguanakan akad Qardh wal ijarah yang diberikan kepada nasabah calon haji dalam rangka memperoleh nomor porsi atau pelunasan BPIH (Surat Edaran Bank Indonesia No. 10/028/PEM, tanggal 1 September 2008). Menurut penulis talangan haji adalah suatu produk yang ada di BSM untuk membantu menalangi masyarakat yang ingin menunaikan ibadah haji di tahun yang akan datang, dimana biaya penalangan ini harus lunas sebelum keberangkatan. 


\section{Pengertian Istilah-istilah yang Berhubungan dengan Talangan Haji}

1. Bank adalah PT Bank Syariah Mandiri.

2. Dana talangan haji adalah pembiayaan dengan menggunakan akad qardh wal ijarah yang diberikan kepada nasabah calon haji dalam rangka memperoleh nomor porsi atau pelunasan $\mathrm{BPIH}$.

3. Pembiayaan adalah penyediaan dana atau tagihan/ piutang yang dapat dipersamakan dengan itu dalam:

a. Transaksi investasi yang didasarkan antara lain atas akad mudharabah, dan musyarakah.

b. Transaksi sewa yang didasarkan antara lain atas akad ijarah atau akad ijarah dengan porsi perpindahan hak milik (IMBT).

c. Transaksi jual beli yang didasarkan antara lain atas akad murabahah, salam dan isthisna'.

d. Transaksi pinjaman yang didasarkan atas akad qardh.

e. Transaksi multi jasa yang didasarkan atas akad ijarah, kafalah dan sebagainya

4. Biaya Penyelenggaraan Ibadah Haji (BPIH) adalah biaya yang dikeluarkan nasabah calon haji untuk menunaikan ibadah haji yang besarnya ditentukan oleh Pemerintah.

5. Sistem Komputerisasi Haji Terpadu (Siskohat) adalah sistem komputerisasi haji terpadu berupa jaringan komputer yang tersambung secara online dan real time antar Direktur Jenderal Penyelenggaraan Haji dan Umrah Departemen Agama RI dengan bank penerima setoran $\mathrm{BPIH}$.

6. Qardh wal ijarah adalah akad yang terjadi antara bank dengan nasabah (calon haji) sehubungan dengan pemberian pinjaman uang oleh bank kepada nasabah untuk memenuhi syarat mendapatkan porsi atau pelunasan BPIH. Bank memungut fee atau biaya administrasi yang wajar atas jasa bank dalam pengurusan kepentingan nasabah

7. Tabungan Mabrur BSM adalah media penyimpanan dana dalam bentuk tabungan di bank yang diperuntukkan bagi masyarakat muslim yang berencana untuk menunaikan ibadah haji dengan sistem tabungan mudharabah al mutlagah

8. Tabungan BSM adalah media penyimpanan dana dalam bentuk tabungan di bank yang penarikannya dapat dilakukan menurut syarat tertentu yang disepakati dengan sistem tabungan mudharabah al mutlaqah

9. PIHK ( Penyelenggara Ibadah Haji Khusus) adalah penyelenggara ibadah haji dengan layanan khusus yang mendapat izin dari Direktur Jenderal Penyelenggaraan Haji dan Umrah Departemen Agama RI atas nama Menteri Agama

10. Nasabah adalah calon haji yang telah mendapat persetujan bank untuk memperoleh fasilitas Dana Talangan Haji.

11. KBIH (Kelompok Bimbingan Ibadah Haii) adalah lembaga yang memiliki kegiatan melakuan bimbingan ibadah haji baik berbentuk yayasan maupun badan usaha (PT, CV, Koperasi, dan lain-lain)

12 Porsi adalah jumlah batasan alokasi pendaftaran jamaah haji yang ditetapkan oleh Menteri Agama

13. Nomor Porsi adalah nomor urutan bagi calon haji yang diberikan secara otomatis dan Siskohat pada saat melakukan penyetoran awal BPIH

14. Calon Haji adalah perorangan yang merencanakan untuk menunaikan ibadah haji

15. Channaling adalah mekanisme penyaluran pembiayaan kepada end user atau calon haji melalui koordinator (KBIH/ PIHK)

16. Joint Collateral / Agunan Bersama adalah penggunaan agunan untuk menjamin beberapa fasilitas pembiayaan nasabah baik 
dalam satu akad atau terdiri dari beberapa akad pembiayaan (Dokumen, t.th: 2-3).

\section{Landasan Hukum Talangan Haji}

1. Alquran

Artinya: "Siapakah yang mau meminjamkan kepada Allah pinjaman yang baik, maka Allah akan melipatgandakan balasan pinjaman itu untuknya, dan dia akan memperoleh pahala yang banyak". (Q.S. al-Hadid [57]:11)

2. Al-Hadis

Dari Anas bin Malik berkata, berkata Rasulullah Saw: "Aku melihat pada waktu malam di isara'kan pada pintu surga tertulis: shadaqah dibalas 10 kali lipat dan qardh 18 kali. Aku bertanya: "Wahai Jibril mengapa qard lebih utama dari shadaqah?" Ia menjawab: "karena peminta-minta sesuai dari ia punya, sedangkan yang meminjam tidak akan meminjamkan kecuali karena keperluan". (HR Ibnu Majah).

3. Para ulama sepakat memperbolehkan qardh karena sesuai dengan tabiat manusia yang tidak dapat hidup tanpa bantuan dan pertolongan saudaranya

4. Opini Dewan Pengawas Syariah PT Bank Syariah Mandiri tentang Biaya Talangan $\mathrm{BPIH}$.

a. Pada prinsipnya kewajiban ibadah haji hanya dibebankan kepada mukallaf yang istitha'ah (mampu). Sehingga seseorang tidak diperkenankan menunaikan haji dengan cara hutang jika ia tidak memilki kesanggupan untuk membayarnya. Apabila ia memilki kekayaan atau harta yang cukup untuk membayar dan diduga kuat untuk melunasinya, maka hal ini diperkenankan oleh sebagian ulama. Berdasarkan hal ini maka konsep "talangan untuk pendaftaran awal Siskohat" dan "talangan kekurangan biaya $\mathrm{BPIH}^{\prime \prime}$ bagi nasabah, terlebih akan dilunasi sebelum keberangkatannya ke Tanah Suci tidak bertentangan dengan prinsip syariah.
Namun demikian, bank perlu mengantisipasi apabila nasabah belum melunasinya pada hari keberangkatan. Maka jika hal ini terjadi maka ahli waris maupun mahram (suami/isteri) yang bersangkutan harus diminta kesediaan sebagai kuasa atau bertanggung jawab melunasinya yang tertuang dalam suatu perjanjian (akad).

b. Akad yang terjadi antara bank dengan nasabah calon haji yang selaras dengan peran dan bantuan bank (untuk meminjamkan kemudian mengurus administratif dan finansial nasabah) adalah akad gardh wal ijarah. Bank mendapat imbalan dalam bentuk fee yang besarnya dapat disepakati kedua belah pihak karena menguruskan kepentingan nasabah (ijarah). Disisi lain bank tidak dapat memark up pinjaman dana talangan kecuali sekedar biaya administrasi bagi keperluan pinjaman murni tersebut (qardh). Akad gardh wal ijarah ini merupakan kesatuan akad yang harus disepakati di awal (Dokumen, t.th.:3-4).

\section{Fatwa Dewan Syari'ah Nasional Tentang Talangan Haji}

Fatwa Nomor 29/DSN-MUI/ VI/2002 tentang Pembiayaan Pengurusan Haji Lembaga KeuanganSyariah

1. Ketentuan Umum

a. Dalam pengurusan haji bagi nasabah LKS dapat memperoleh imbalan jasa (ujrah) dengan menguunakan prinsip al-ijarah

b. Apabila diperlukan, LKS dapat membantu menalangi pembayaran BPIH nasabah dengan menggunakan prinsip $A l$ - Qardh

c. Jasa pengurusan haji dilakukan LKS tidak boleh dipersyaratkan dengan pemberian talangan haji

d. Besar imbalan jasa Al- Ijarah tidak boleh didasarkan pada jumlah talangan Al- 
Qardh yang diberikan LKS kepada nasabah.

2. Ketentuan Penutup

a. Jika salah satu pihak tidak menunaikan kewajibannya atau jika terjadi perselisihan diantara kedua belah pihak maka, penyelesaiannya dilakukan melalui Badan Arbitrase Syariah setelah tidak tercapai kesepakatan melalui musyawarah.

b. Fatwa ini berlaku sejak tanggal ditetapkan degan ketentuan jika dikemudian hari ternyata terdapat kekeliruan, akan diubah dan disempurnakan sebagai mana mestinya.

Ditetapkan di Jakarta, 15 Rabiul Akhir 1423

H/ 26 Juni 2002 M (Dewan Syariah Nasional Majelis Ulama Indonesia, 2003: 179-180).

\section{Dasar Hukum Formal Talangan Haji}

1. Anggaran Dasar PT Bank Syariah Mandiri berikut perubahannya

2. Kebijkan Pembiayaan PT Bank Syariah Mandiri

3. Kebijakan Manajemen Risiko PT Bank Syariah Mandiri

4. Pedoman Pembiayaan PT Bank Syariah Mandiri

5. Undang -Undang No. 13 tahun 2008 perihal Penyelenggaraan Ibadah Haji

6. PBI No.5/8/PBI/2003, tanggal 19 mei 2003 tentang Penerapan Manajemen Risiko bagi Bank Umum

7. Fatwa Dewan Syariah Nasional No. 19/ DSNMUI/LX/2000 tentang Al Qardh

8. Fatwa Dewan Syariah Nasional No. 29/DSNMUI/VI/2002 tentang Pembiayaan Pengurusan Haji Lembaga Keuangan Syariah.

9. Opini Dewan Pengawas Syariah Bank Syariah Mandiri atas Biaya Talangan Haji $\mathrm{ONH}$ vide surat tanggal 28 Muharram $1421 \mathrm{H}$ tanggal 3 Mei 2000 (Dokumen, t.th.: 1).

\section{Ketentuan Pelaksanaan Talangan Haji}

Ketentuan Pokok

Talangan Pendaftaran Haji yaitu talangan untuk menutup kekurangan setoran pendaftaran haji melalui Siskohat guna mendapatkan nomor porsi keberangkatan haji. Talangan Pelunasan $\mathrm{BPIH}$ yaitu talangan untuk menutup kekurangan pelunasan $\mathrm{BPIH}$ saat masa pelunasan $\mathrm{BPIH}$. Dana Talangan Haji hanya dapat diberikan kepada nasabah yang mengalami kesulitan uang tunai pada saat pendaftaran haji melalui Siskohat untuk mendapatkan nomor porsi dan atau saat masa pelunasan BPIH. Kriteria kesulitan uang tunai, karena nasabah sedang menunggu: Uang tunai pembayaran tagihan dari hasil usaha yang dapat diyakini kebenarannya (dibuktikan dengan media piutang yang sah seperti wesel tagih) dan bisa tertagih pada tanggal yang diperjanjikan Uang tunai dari pencairan deposito yang akan jatuh tempo yang dibuktikan adanya asli bilyet deposito dan telah diyakini kebenarannya. Uang tunai dan hasil penjualan fixed asset yang dibuktikan dengan asli bukti kepemilikan fixed asset dan telah ada pihak yang akan mambeli fixed asset.

Pemohon Talangan Pendaftaran Haji adalah calon haji melalui $\mathrm{KBIH} / \mathrm{PIHK}$ maka peberian menggunakan pola channeling. Pemohon Talangan Pelunasan BPIH adalah calon haji.

Pelunasan dana talangan haji dapat dilakukan dengan dua cara yaitu pelunasan sekaligus pada saat jatuh tempo dana talangan haji dan pelunasan secara angsuran sesuai waktu yang telah disepakati dengan mengacu kepada kondisi keuangan nasabah yang mendasari diberikannya Dana Talangan Haji. Sumber dana fasilitas Dana Talangan Haji berasal dari modal bank (Dokumen, t.th:: 4).

Sedangkan wewenang Penanganan dana talangan haji Pemberian dan penanganan Dana Talangan Haji dilakukan oleh Kantor Cabang dan Divisi Pembiayaan Konsumer (DPK). 


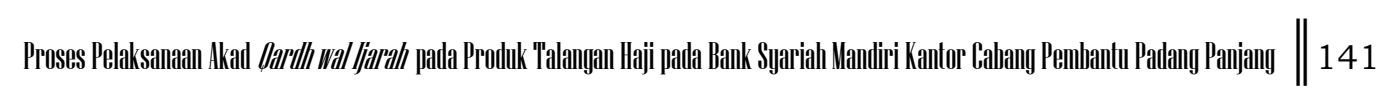

Kemudian divisi Operasi dan Akuntansi (DOA) berwenang untuk melakukan penghentian sementara penggunaan Dana Talangan Haji setelah terlebih dahulu berkoordinasi Divisi Dana Internasional (DTI) dan Divisi Pembiayaan Komersial (DPK) khususnya bila penggunaan dana modal hampir melampaui limit yang ditetapkan.

Untuk proses Penanganan secara garis besar, langkah-langkah penanganan Dana Talangan Haji sebagai berikut:

1. Cabang menerima permohonan Dana Talangan Haji dari nasabah

2. Cabang melakukan analisa atas kelayakan permohonan yang diajukan nasabah dengan mengacu pada Kebijakan dan Pedoman Pembiayaan PT BankSyariah Mandiri

3. Cabang melakukan pembukaan rekening Tabungan Mabrur BSM atas nama nasabah/ calon haji

4. Cabang meminta nasabah untuk memenuhi saldo minimal Tabungan Mabrur BSM, self financing biaya pendaftaran haji sebagai dasar pengajuan Talangan Pendaftaran Haji dan biaya-biaya yang dikenakan kepada nasabah

5. Cabang melakukan penanda tanganan akad dengan nasabah/ kuasanya di bawah tangan

6. Cabang melakukan proses pencairan talangan ke rekening Tabungan Mabrur BSM milik nasabah

7. Cabang menguasai dokumen- dokumen yang dipersyaratkan

8. Cabang melakukan entry ke Siskohat untuk mendaftarkan nasabah atau calon haji dan menahan lembar pertama bukti setoran awal BPIH (Dokumen, t.th.: 9). Proses akad qard wal ijarah pada produk talangan haji di BSM Padang Panjang. Pada saat pelaksanaan akad pembiayaan talangn haji nasabah wajib memiliki beberapa persyaratan sebagai syarat untuk mengajukan permohonan pembiayaan talangan haji di BSM KCP Padang Panjang. Syarat- syarat tersebut terdiri dari Permohonan dana talangan haji, menandatangi perjanjian jika seandainya nasabah tidak melunasi biaya talangan sebelum keberangkatan maka bank berhak membatalkan nasabah tersebut untuk menunaikan ibadah haji. Mengisi identitas diri sesuai dengan tanda pengenal calon nasabah (KTP/SIM).

Kemudian bank akan langsung memfasilitasi pengambilan porsi setelah bank memfasilitasi dana talangan haji maka nasabah akan mengetahui tahun nasabah talangan haji kepada Siskohat keberangkatannya. Setelah bank memfasilitasi dana talangan haji maka nasabah calon haji dapat melunasi dana talangan tersebut dengan dua cara yaitu: pelunasan pada saat jaatuh tempo dana talangan dan pelunasan secara angsuran sesuai waktu yang telah disepakati dengan mengacu kepada kondisi keuangan nasabah yang mendasari diberikannya dana talangan haji (Nurul Muslim, operasional officer BSM Padang Panjang, wawancara tanggal 27 Februari 2013).

Biaya penyelenggaraan ibadah haji yaitu sebanyak Rp. 25.000.000,00 di mana bank memfasilitasi sebanyak Rp. 22.500.000,00. ditambah biaya ujrah sebesar Rp. 2.000.000,00 dan biaya Rp. 500.000,00. Oleh karena itu nasabah harus menyediakan dana sebanyak administrasi dan biaya asuransi sebesar Rp. 500.000,00. Jadi nasabah calon haji harus membayar sebesar Rp. 5.000.000,00 di awal akad. Sisa Rp. 22.500.000,00 menjadi tanggung jawab bank (yang dikenal dengan talangan) (Nurul Muslim, operasional officer BSM Padang Panjang, wawancara tanggal 27 Februari 2013). Ujrah merupakan imbalan jasa bank setelah memfasilitasi pengambilan porsi talangan haji, sebagai mana yang tercantum dalam fatwa DSN-MUI No. 9/ DSNMUI/IV/2000.

Sementara untuk proses pemberian talangan digunakan akad qardh, karena talangan haji bukan termasuk kedalam kegiatan produktif. Sebagaimana yang diatur dalam fatwa DSN- 
MUINo. 19/ MUI/IV/2001 yang isinya: Apabila diperlukan LKS dapat membantu menalangi pembayaran BPIH nasabah dengan menggunakan prinsip al-qardh. Untuk produk talangan haji ini, nasabah tidak perlu memberikan agunan, karena jika seandainya nasabah tidak mampu melunasi pembiayaan talangan maka Bank akan membatalkan penyelenggaraan ibadah haji nasabah tersebut melalui Siskohat, dan nasabah bisa memperoleh uangnya kembali setelah dikurangi biaya- biaya.

\section{PENUTUP}

Untuk pembiayaan dana talangan haji oleh BSM cabang pembantu kota padang panjang sudah mengacu kepada fatwa MUI Tentang Dana Talangan haji dengan ketentuan pelunasan dana talangan haji harus diselesaikan oleh nasabah sebelum berangkat melaksanakan ibadah Haji. Bank berhak membatalkan keberangkatan nasabah jika nasabah tidak mampu melunasi pembiayaan menjelang keberangkatan. Sedangkan keuntungkan bagi Bank dapat memperoleh ujrah sesuai kesepakatan bank dengan nasabah. Sedangkan untuk nasabah diwajibkan membayar biaya administrasi dan biaya asuransi yang berhubungan dengan pelaksanaan akad. Sementara keuntungan bagi nasabah yaitu nasabah bisa memperoleh porsi terlebih dahulu dan nasabah bisa mencicil dana untuk keberangkatannya ke Tanah Suci.

\section{DAFTAR KEPUSTAKAAN}

Antonio, Syafi'i Muhammad, Bank Syariah Dari Teorike Praktik. Gema Insani, Depok, 2001

Ascarya, Akad dan Produk Perbankan Syariah. PT Grafindo Persada Jakarta, 2007
A. Karim Adiwarman. Bank Islam Analisis Fiqih dan Keuangan. Ed.4. Cet.7 Jakarta: PT Raja Grafindo Persada, 2010

Azzam , Abdul Aziz Muhammad, Fiqh Muamalat system Transaksi dalam Figh Islam. Jakarta: Amzah, 2010

Sunarto, Zulkifli. Panduan PraktisTransaksi Perbankan Syariah. Zikrul Hakim. Jl. Pramuka Raya No. 4 Jakata Timur 13140

Djasmi, Kegiatan Usaha Bank Syariah. Hayfa Press, Jl. Bandar Purus No.57 C Padang

Muhammad. Akuntansi Perbankan Syariah. Sleman, Yogyakarta 2009

Martono, Bank dan Lembaga Keuangan Lain. Yogyakarta, Ekonisia, 2002

Nasrun Haroen, DR, MA. Figh Muamalah. Gaya Media Pratama, Jakarta, 2000

Nurhayati Sri-wasilah, Akuntansi Syariah di Indonesia. Salemba 4

Sholahuddin, Lembaga ekonomi dan keuangan Islam. Surakarta: MUP-UMS, 2006

Sudarsono, Heri, Bank dan Lembaga Keuangan Syariah Skripsi dan Ilustrasi. Yogyakarta: Ekonisa, 2003

Yusak, Laksamana, Panduan Praktis Accont Officer Bank Syariah. PT Elex Media Komputindo Kelompok Gramedia -Jakarta. Anggota IKAPI, Jakarta 2009

Nasib ar-Rifa'i, 1999. Muhammad, Ringkasan Tafsir Ibnu Katsir. Jakarta : Gema Insani, Cet ke-1, Jilid 1.

Nelli Jumni, M. Ag, 2008. Figh Munakahat. Pekanbaru:Suska Press.

Sayyid Quthb, Syahid, Penerjemah : As'ad Yasin, Abdul Aziz Salim Basyarahil dan Muchotob Hasan, 2001. Tafsir Fi Zhilalil Qur an.Jakarta : Gema Insani Press, Cet. Ke-1 

